\title{
Anthelmintic resistance in a dairy cattle farm in the State of Minas Gerais
}

\author{
Resistência anti-helmíntica em uma propriedade de bovinos leiteiros em Minas Gerais \\ Maria do Socorro Veloso Leite Ferraz da Costa ${ }^{1 *}$; Ricardo Nascimento Araújo후 \\ Ana Júlia Leite Ferraz da $\operatorname{Costa}^{2}$; Rafael Ferreira Simóes ${ }^{2}$; Walter dos Santos Lima ${ }^{1}$ \\ ${ }^{1}$ Departamento de Parasitologia, Instituto de Ciências Biológicas - ICB, Universidade Federal de Minas Gerais - UFMG \\ ${ }^{2}$ Universidade Federal de Minas Gerais - UFMG
}

Received August 6, 2010

Accepted April 7, 2011

\begin{abstract}
Eighty-four half-blood Gir $\times$ Holstein (F1) calves aged six months who were naturally infected by gastrointestinal helminths and maintained in rotational grazing received different anthelmintic treatments. Group A received anthelmintics according to the usual management in the property (eight treatments, seven including a macrocyclic lactone agent). Group B received strategic treatment (ivermectin 3.15\%) at the beginning and at the end of the rainy period. Eggs per gram of feces (EPG) counts and genus of larvae from fecal cultures were determined on a monthly basis from April 2002 to December 2003. There was no significant reduction ( $p>0.05)$ in EPG counts in any group after anthelminthic treatment, and the larvae in fecal cultures observed were Cooperia, Haemonchus, Oesophagostomum and a few Trichostrongylus. Cooperia was the most prevalent genus in the first four months of the experiment and Haemonchus in the following months. In 2003, tracer calves were introduced onto the pastures monthly and they showed high nematode burden many times throughout the year, and Cooperia punctata and Haemonchus contortus were the main species identified. The results suggest that there is anthelminthic resistance in this farm, mainly to macrocyclic lactones, and the development of immunity by crossbred animals was vital to reduce nematode burden.
\end{abstract}

Keywords: Cattle, anthelmintic resistance, Cooperia, macrocyclic lactone, Haemonchus.

\section{Resumo}

Oitenta e quatro bezerras meio sangue Gir $\times$ holandês (F1) com seis meses de idade, naturalmente infectadas por helmintos gastrintestinais e mantidas em pastejo rotacionado receberam diferentes tratamentos anti-helmínticos. O grupo A recebeu anti-helmínticos segundo manejo empregado na propriedade (oito tratamentos, sete com produtos à base de lactonas macrocíclicas). $\mathrm{O}$ grupo $\mathrm{B}$ recebeu tratamento estratégico (ivermectina 3,15\%) no inicio e final de período chuvoso. Mensalmente, no período de abril de 2002 a dezembro de 2003, foram realizadas contagens de ovos por grama de fezes (OPG) e coproculturas. Não houve reduçáo significativa $(\mathrm{p}>0,05)$ nas contagens de OPG em nenhum dos grupos após os tratamentos anti-helmínticos, e as larvas encontradas na coprocultura foram Cooperia, Haemonchus, Oesophagostomum e poucos Trichostrongylus, com predominância de Cooperia nos quatro meses iniciais e Haemonchus nos meses seguintes. No ano de 2003, bezerros traçadores foram alocados mensalmente nos pastos, apresentando altas cargas parasitárias na maioria dos meses do ano, sendo as principais espécies identificadas: Cooperia punctata e Haemonchus contortus. Os resultados indicam que os nematódeos da fazenda apresentam resistência anti-helmíntica, principalmente às lactonas macrocíclicas, e o desenvolvimento de imunidade foi primordial para reduzir a carga parasitária dos animais mestiços.

Palavras-chave: Bovinos, resistência anti-helmíntica, Cooperia, lactonas macrocíclicas, Haemonchus.

\footnotetext{
*Corresponding author: Maria do Socorro Veloso Leite Ferraz da Costa

Departamento de Parasitologia, Instituto de Ciências Biológicas - ICB,

Universidade Federal de Minas Gerais - UFMG, Av. Antonio Carlos, 6627,

CP 486, CEP 31270-901, Belo Horizonte - MG, Brazil;

e-mail: socorrovferraz@yahoo.com.br
} 


\section{Introduction}

Brazil has the largest commercial cattle herd and is the second leading meat producer in the world, and meat production is a major national source of income (BARBOSA; MOLINA, 2006). Foreign market opening up together with a global growing interest in the production of pasture-fed animals, free of chemical products and residues in feed of animal origin, can make the external market more attractive to producers, since most cattle is extensively raised. In order to meet this potential demand it is important to increase effectiveness of production, which is closely related to appropriate conditions of animal sanitation, genetic selection and nutrition (VERCRUYSSE; DORNY, 1999).

Animal sanitation involves the control of worm parasitic infections with the use of anthelmintics based on strategic control programs associated with support management aiming to avoid reinfection and delay the emergence of resistance thus maintaining parasite burdens low enough to create protective immunity to the host and prevent economic losses (BORDIN, 2004). However, frequent use of anthelmintics has promoted the development of resistance to different agents used in several regions in Brazil (CONDI et al., 2009; SOUTELLO et al., 2007; SOUZA et al., 2008). Farmers usually fail to notice the growth of helminth populations resistant to anthelmintics and, sometimes even veterinarians fail to notice it as treatment failure is not clinically evident and can only be identified with proper investigation, as well as unawareness of emerging anthelmintic resistant intestinal nematodes.

The purpose of the present study was to evaluate the performance and parasite infection of Gir calves after treatment with two anthelmintic regimens including endoparasiticides commonly used in dairy cattle to control intestinal nematodes.

\section{Material and Methods}

The study was carried out from April 2002 to December 2003 in a typical dairy cattle farm in the Vale do Mucuri located in the municipality of Teófilo Otoni (17 $51^{\prime} 15^{\prime \prime} \mathrm{W}$ and $41^{\circ} 30^{\prime} 23^{\prime \prime} \mathrm{S}$ ), in the State of Minas Gerais, southeastern Brazil.

Eighty-four weaned calves aged from five to eight months (mean $6.4 \pm 0.8$ months in the beginning of the experiment) were identified with ear tags and, during the experimental period, kept in rotational grazing in an area of 18 hectares covered with pasture grass Braquiaria brizanta, with one day of grazing and 30 days of rest with food supplements, mineral salt, and water. Two months prior to the beginning of treatment (April 2002), the animals were evaluated as for eggs per gram of feces (EPG) counts, and were categorized by weight and divided into two groups (A and B). Table 1 shows anthelmintic treatments applied.

After the beginning of treatments, calves were gathered and individually weighed on a monthly basis. Their feces were then collected directly from the rectal ampulla for EPG counts according to the modified Gordon and Whitlock (1939) method and stool cultures following the modified method proposed by Roberts and O'Sullivan (1950). Larvae present in stool cultures were identified using Keith parameters (1953).
Table 1. Anthelminthic treatments applied to calves in group A (according to the usual management in the farm) and B (in June and October 2002 and May and October 2003), Minas Gerais, Brazil, from April 2002 to December 2003.

\begin{tabular}{ccc}
\hline Month & Group A & Group B \\
\hline 2002 & & \\
\hline June & ${\text { Ivermectin } 1 \%{ }^{\mathrm{a}}}^{\mathrm{a}}$ & Ivermectin 3.15\% ${ }^{\mathrm{a}}+$ Fibronil $^{\mathrm{b}}$ \\
Aug. & Albendazole sulfoxide & - \\
Sept. & Ivermectin 1\% & - \\
Oct. & - & Ivermectin 3.15\% \\
Nov. & Ivermectin 1\% & - \\
\hline 2003 & & \\
\hline May & Abamectin $1 \%{ }^{\mathrm{a}}$ & Ivermectin 3.15\% \\
June & Abamectin $1 \%$ & - \\
Aug. & Ivermectin $1 \%$ & - \\
Oct. & Doramectin $1 \%{ }^{\mathrm{a}}$ & Ivermectin 3.15\% \\
\hline
\end{tabular}

${ }^{a}$ Injectable, $1 \mathrm{~mL} / 50 \mathrm{~kg}$ subcutaneously; ${ }^{\text {b Pour on, } 1 \mathrm{~mL} / 10 \mathrm{~kg} \text {, Merial }}$ Laboratórios.

From January to December 2003, helminthic infestation in pastures was monitored using tracer calves (Holstein $\times$ Zebu crossbred) aged 5 to 7 months, prepared according to Lima (1998). Tracers were introduced monthly into pastures together with calves on the first day and removed on the last day of the month, when they were kept in stalls made of brickwork with concrete-paving floors, and fed with hay and water ad libitum for 15 days. After this period, animals were sacrificed and then necropsied using the technique as described by Costa et al. (1970). Helminths recovered were identified following Douvres (1957) and Yamaguti (1961) procedures.

Information on rainfall index and maximum and minimum temperatures during the study period were collected from a weather station located in the farm.

Data on EPG counts and weight gain were analyzed using the Kolmogorov-Smirnov test to evaluate normality. The analysis of variance (ANOVA) with repeated measures and Bonferroni multiple comparison test were performed to assess differences between groups. In order to assess differences between the months studied, one-factor ANOVA was used followed by Tukey's test. Pearson's correlation coefficient was used to assess potential correlations among variables. The analyses were carried out using GraphPad Prism 5 (GraphPad Inc.) software. The level of significance adopted was $\mathrm{p}<0.05$.

\section{Results and Discussion}

During the study period, the average temperature ranged from 22 to $33{ }^{\circ} \mathrm{C}$, except in June 2003 when it was lower, with an average minimum temperature of $13{ }^{\circ} \mathrm{C}$. Two seasons were defined by rainfall with slightly varying duration in the years studied. In 2002, the driest period was from April to July, whereas in 2003 it was from May to October. The wet period was from September 2002 to April 2003, with a late start (in November) in 2003 (Figure 1). 
As for EPG counts, there was no significant reduction of counts in any of the groups after the beginning of anthelmintic treatment (Figure 2). Except for January 2003, EPG counts in April and June were not statistically different $(p>0.05)$ from counts performed from July 2002 to May 2003. EPG counts were significantly lower $(\mathrm{p}<0.05)$ from June to December 2003 when compared with pre-treatment months (April and June 2002). This reduction seen in the fifteenth month after the beginning of treatment cannot be explained by anthelmintic treatment and was not significantly correlated to rainfall. Pearson's correlation coefficient between EPG counts and rainfall was $r=0.36$, showing low impact of rainfall on EPG counts.

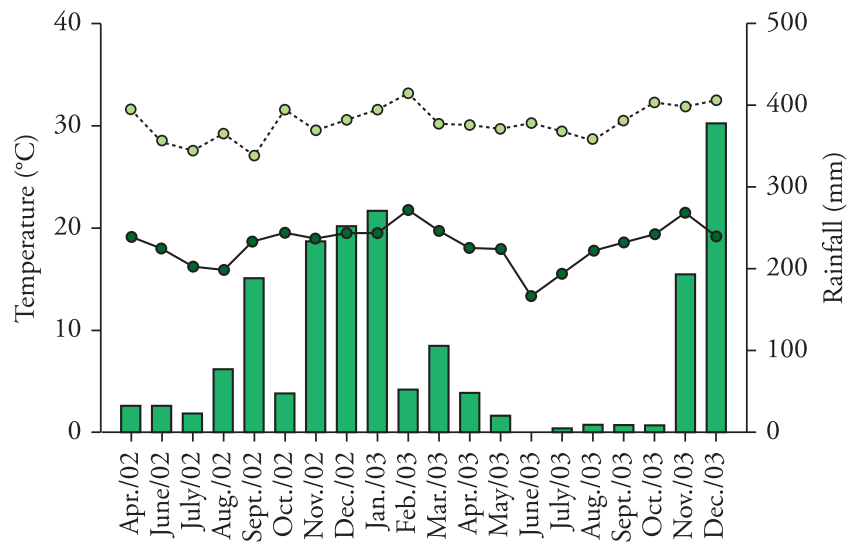

Rainfall $\rightarrow$ Minimum temperature $\quad$-.-.- Maximum temperature

Figure 1. Mean temperature and rainfall during the period of April/02 to December/03.
The variable with the strongest correlation with EPG counts was age. In June 2003, animals were about 18.4 months old, which is the age when cattle usually develop immune resistance to intestinal nematodes and are able to fight infection leading to lower egg production by females and thus lower EPG counts (GASBARRE et al., 2001; LIMA, 1998). The Pearson's correlation coefficient between EPG counts and age was 0.58 , but only when the last 11 months of the experimental period was considered, which corresponds to 14.4 to 24.4 months of age and consequently to the main period of immunity development by the animals, when the correlation coefficient was very high $(r=0.93)$. These results showed that nematodes in the farm studied were resistant
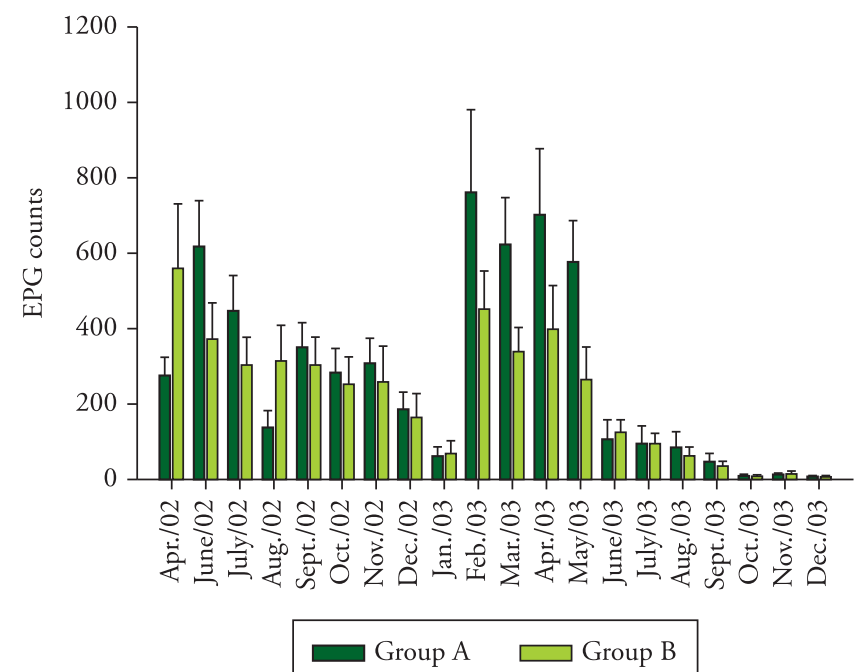

Figure 2. Mean EPG counts of groups A and B during the period of April/02 to December/03.

Table 2. Monthly means of nematode larvae recovered from stool cultures in groups A and B, Minas Gerais, Brazil, from April 2002 to December 2003.

\begin{tabular}{|c|c|c|c|c|c|c|c|c|}
\hline \multirow[t]{2}{*}{ Month } & \multicolumn{2}{|c|}{ Cooperia } & \multicolumn{2}{|c|}{ Haemonchus } & \multicolumn{2}{|c|}{ Oesophagostomum } & \multicolumn{2}{|c|}{ Trichostrongylus } \\
\hline & A & B & A & B & A & B & A & B \\
\hline \multicolumn{9}{|l|}{2002} \\
\hline Apr. & 83.9 & 89.8 & 15.8 & 10.0 & 0.2 & 0.1 & 0.0 & 0.1 \\
\hline June & 68.2 & 63.2 & 30.9 & 34.9 & 0.9 & 1.8 & 0.0 & 0.0 \\
\hline July & 78.5 & 79.9 & 21.5 & 20.1 & 0.0 & 0.0 & 0.0 & 0.0 \\
\hline Aug. & 93.7 & 53.5 & 6.3 & 46.5 & 0.0 & 0.0 & 0.0 & 0.0 \\
\hline Sept. & 36.3 & 29.4 & 62.8 & 70.6 & 0.9 & 0.0 & 0.0 & 0.0 \\
\hline Oct. & 29.5 & 24.8 & 69.8 & 75.2 & 0.7 & 0.0 & 0.0 & 0.0 \\
\hline Nov. & 16.5 & 18.8 & 83.5 & 81.2 & 0.0 & 0.0 & 0.0 & 0.0 \\
\hline \multicolumn{9}{|l|}{2003} \\
\hline Jan. & 25.3 & 35.4 & 74.0 & 64.6 & 0.7 & 0.0 & 0.0 & 0.0 \\
\hline Feb. & 5.3 & 5.8 & 93.3 & 93.9 & 1.4 & 0.2 & 0.0 & 0.0 \\
\hline Mar. & 2.9 & 4.4 & 91.2 & 91.1 & 5.9 & 4.5 & 0.0 & 0.0 \\
\hline Apr. & 1.7 & 1.4 & 84.4 & 84.6 & 13.8 & 13.9 & 0.0 & 0.0 \\
\hline May & 1.5 & 3.8 & 89.7 & 77.3 & 8.8 & 18.9 & 0.0 & 0.0 \\
\hline June & 14.6 & 4.5 & 85.4 & 95.5 & 0.0 & 0.0 & 0.0 & 0.0 \\
\hline Aug. & 20.3 & 4.1 & 60.7 & 74.4 & 17.8 & 21.3 & 1.1 & 0.2 \\
\hline Oct. & 3.8 & 19.9 & 93.9 & 19.7 & 2.2 & 60.3 & 0.0 & 0.0 \\
\hline Nov. & 62.7 & 93.0 & 36.1 & 0.0 & 0.0 & 0.0 & 1.2 & 7.0 \\
\hline Dec. & 26.5 & 60.3 & 71.2 & 36.6 & 2.3 & 3.1 & 0.0 & 0.0 \\
\hline
\end{tabular}


Table 3. Species and number of nematodes recovered from necropsies of tracer animals, Minas Gerais, Brazil, from January to December 2003.

\begin{tabular}{|c|c|c|c|c|c|c|c|c|c|c|}
\hline Species $\backslash$ month & Jan. & Feb. & Mar. & Apr. & May & June & Aug. & Oct. & Nov. & Dec \\
\hline \multicolumn{11}{|l|}{ Cooperia punctata } \\
\hline Adults & 6 & 6 & 583 & 1 & 2195 & 6638 & 13 & 838 & 11 & 943 \\
\hline Immature* & 0 & 0 & 26 & 1 & 147 & 743 & 3 & 330 & 1 & 100 \\
\hline Total & 6 & 6 & 609 & 2 & 2342 & 7381 & 16 & 1168 & 12 & 1043 \\
\hline \multicolumn{11}{|l|}{ Haemonchus contortus } \\
\hline Adults & 716 & 519 & 200 & 368 & 529 & 734 & 67 & 166 & 6 & 973 \\
\hline Immature & 226 & 45 & 62 & 554 & 349 & 64 & 120 & 12 & 6 & 336 \\
\hline Total & 942 & 564 & 262 & 922 & 878 & 798 & 187 & 178 & 12 & 1309 \\
\hline \multicolumn{11}{|c|}{ Oesophagostomum radiatum } \\
\hline Adults & 2 & 5 & 2 & 0 & 9 & 23 & 1 & 3 & 5 & 3 \\
\hline Immature & 1 & 0 & 0 & 0 & 0 & 0 & 1 & 0 & 1 & 8 \\
\hline Total & 3 & 5 & 2 & 0 & 9 & 23 & 2 & 3 & 6 & 11 \\
\hline \multicolumn{11}{|l|}{ Trichuris discolor } \\
\hline Adults & 3 & 4 & 0 & 0 & 0 & 3 & 4 & 7 & 7 & 8 \\
\hline Immature & 0 & 0 & 0 & 0 & 4 & 0 & 0 & 0 & 1 & 3 \\
\hline Total & 3 & 4 & 0 & 0 & 4 & 3 & 4 & 7 & 8 & 11 \\
\hline Total & 954 & 579 & 873 & 924 & 3233 & 8205 & 209 & 1356 & 38 & 2374 \\
\hline
\end{tabular}

to albendazole and macrocyclic lactones, even in formulations with higher concentration (such as ivermectin 3.15\%). EPG count reduction lower than $90 \%$ indicates anthelmintic resistance (MOLENTO, 2004; SOUTELLO et al., 2007). In the study area, the results show the occurrence of resistance; however, it is not possible to infer about the level of resistance as more specific protocols are needed to evaluate it (MOLENTO, 2004).

Overall, EPG counts in group B were slightly lower than those in group $A$, however, there was not significant difference ( $p>0.05)$. EPG counts were never negative in any monthly analysis, probably due to anthelmintic resistance acquired by nematodes against the agents used together to treat reinfection of the animals by infective larvae present in pastures. These results showed that the study treatments were not effective in reducing parasite burden, and the difference between the groups was masked by the high level of resistance to macrocyclic lactones by the nematodes in this farm.

Nematode larvae recovered in stool cultures were basically classified in four genera as follows: Cooperia, Haemonchus, Oesophagostomum and Trichostrongylus (Table 2).Cooperia and Haemonchus larvae were obtained from stool cultures of animals throughout the experimental period and were more predominant than other genera. Cooperia was the most predominant genus in the beginning of the experimental period (April to August 2002), however its prevalence was reduced two months after the beginning of treatment (September 2002) in detriment of or due to increase in the prevalence of Haemonchus larvae, which had higher rates when compared to other genera from September 2002. Oesophagostomum larvae were infrequently observed, however, as well as Haemonchus larvae, they showed growing rates after the beginning of treatment and were more abundant from January to October 2003. Larvae of Trichostrongylus were sporadically recovered, seen only in stool cultures from April 2002 and August and November 2003 (Table 2). A Bunostomum larvae was found in the stool culture of an animal in group A in March 2003. These variations observed in genus prevalence suggest that Cooperia, despite its resistance to the anthelmintics used, was the genus with the most significant reduction after the beginning of treatment. The genera Haemonchus and Oesophagostomum showed the highest levels of resistance to macrocyclic lactones and were more frequently seen only after the beginning of the anthelmintic treatment. Another fact that may have influenced genus prevalence is acquired immunity by the animals. Anti-Cooperia immunity is acquired at an earlier age (starting when the animals are four months old), while for the genera Haemonchus and Trichostrongylus the reduction of parasite burden is more slowly and occurs at an older age (ARMOUR, 1989). These variations were also observed by Araujo and Lima (2005) in animals without anthelmintic treatment raised in other regions of the State of Minas Gerais.

Among the helminths recovered from the necropsies of tracer calves (Table 3), Cooperia punctata was the species found in the largest number, peaking in months of low rainfall (May, June and October 2003). This may be explained by high resistance of infective larvae in the environment as this genus thrives with lower rainfall ( 5 to $7 \mathrm{~mm}$ ) than larvae from other genera, and has a higher migration capacity (DURIE, 1962; ROBERTS et al., 1951). This genus frequently occurs in cattle from other regions and shows high levels of recovery in tracer cattle from other studies (ARAUJO; LIMA, 2005; FURLONG et al., 1985; GUIMARÃES et al., 1975).

The second most recovered species from tracer animals during the study period was Haemonchus contortus. It showed the highest frequency during the months with the highest average rainfall January and December 2003, but relatively higher frequencies from February to June 2003. Oesophagostomum radiatum was recovered from tracer animals nearly every month, but always at lower rates, not exceeding 23 helminths.

A significant number of immature larvae were recovered during necropsy in all months of 2003, accounting for up to 


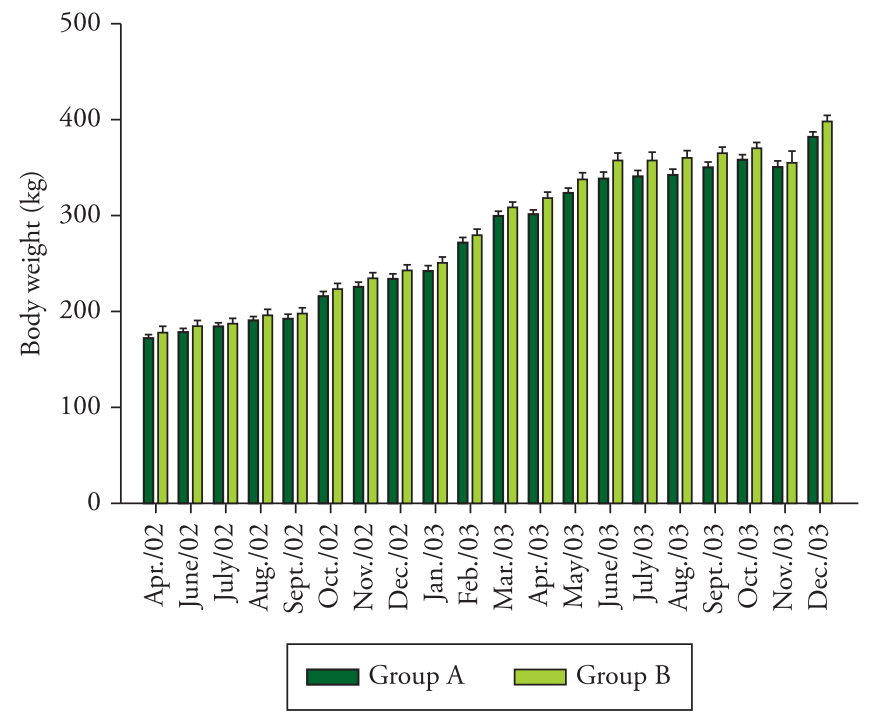

Figure 3. Mean body weight of animals from groups A and B during the period of April/02 to December/03.

50 and 64\% for Cooperia and Haemonchus, respectively. These findings, together with the total number of nematodes recovered from tracer animals, which was higher than 500 in eight out of the ten months analyzed, indicate that infective larvae were available in pastures throughout the experiment period, even in months with lower rainfall and temperature and the use of rotational grazing and anthelmintic treatment. These findings reinforce the evidence that animal acquired immunity was the main factor contributing to EPG count reduction and it indicates that heifers managed to control infection even when repeatedly challenged with infective larvae.

The mean weight of calves was 171 and $177 \mathrm{~kg}$ in groups $\mathrm{A}$ and $\mathrm{B}$ at the beginning of the experiment, and they were 211 and $221 \mathrm{~kg}$, respectively, by the end of the experiment (Figure 3), even with intestinal nematode parasitism that was not controlled by anthelmintic treatment. The use of animals genetically resistant to intestinal nematodes is extremely important in areas where anthelmintic resistance is established (GASBARRE et al., 2001). As expected, animals gained more weight after the rainy months (October 2002 to May 2003). There was no statistically significant difference $(\mathrm{p}>0.05)$ regarding the weight of animals in groups A and B in any of the months studied, probably because no treatment was effective to control nematodes.

\section{Conclusions}

Nematodes showed drug resistance in the farm studied, mainly to the most commonly used agents in the property, such as macrocyclic lactones, and Haemonchus and Oesophagostomum genera were more resistant than Cooperia. The main factor contributing to the reduction of parasite burden was animal acquired immunity, which occurred when they were about 18 months old. The study results show the advantages of raising crossbred animals, such as Gir, to minimize damages caused by intestinal nematodes in areas of anthelmintic resistance. The effectiveness of anthelmintics should be evaluated to identify the most effective agents to control intestinal nematodes in the farm.

\section{References}

ARAUJO, R. N.; LIMA, W. S. Infecçôes helmínticas em um rebanho leiteiro na regiáa Campos das Vertentes de Minas Gerais. Arquivo Brasileiro de Medicina Veterinária e Zootecnia, v. 57, p. 186-193, 2005. Suplemento 2 .

ARMOUR, J. The influence of host immunity on the epidemiology of trichostrongyle infections in cattle. Veterinary Parasitology, v. 32, n. 1, p. 5-19, 1989. http://dx.doi.org/10.1016/0304-4017(89)90152-0

BARBOSA, F. A.; MOLINA, L. R. Conjuntura da carne bovina no mundo e no Brasil. In: ANUÁRIO da Pecuária Brasileira - Anualpec. São Paulo: Instituto FNP, 2006.

BORDIN, E. L. Algumas consideraçôes sobre a resistência de nematodas gastrintestinais de ruminantes aos antihelmínticos. Revista Brasileira de Parasitologia Veterinária, v. 13, p. 80-81, 2004. Suplemento 1.

CONDI, G. K.; SOUTEllO, R. G. V.; AMARANTE, A. F. T. Moxidectin-resistant nematodes in cattle in Brazil. Veterinary Parasitology, v. 161, n. 3-4, p. 213-217, 2009. PMid:19251366. http://dx.doi.org/10.1016/j.vetpar.2009.01.031

COSTA, H. M. A.; FREITAS, M. G.; GUIMARÃES, M. P. Prevalência e intensidade de infestaçáo por helmintos de bovinos procedentes da área de Três Coraçóes. Arquivo da Escola de Veterinária da Universidade Federal de Minas Gerais, v. 22, n. 1, p. 95-101, 1970.

DOUVRES, F. W. Keys to the identification and differentiation of the immature parasitic stages of gastrointestinal nematodes of cattle. American Journal of Veterinary Research, v. 18, n. 66, p. 81-85, 1957.

DURIE, P. H. Parasitic gastroenteritis of cattle: Seasonal fluctuations of strongyle larvae on a calf pasture and their significance in infection of the grazing animal. Australian Journal of Agricultural Research, v. 13, p. 767-777, 1962. http://dx.doi.org/10.1071/AR9620767

FURLONG, J.; ABREU, H. G. L.; VERNEQUE, R. S. Parasitoses dos bovinos na regiāo da Zona da Mata de Minas Gerais: I- comportamento estacional de nematódeos gastrointestinais. Pesquisa Agropecuária Brasileira, v. 20, n. 1, p. 143-153, 1985.

GASBARRE, L. C.; LIEGHTON, E. A.; SONSTEGARD, T. Role of the bovine immune system and genome in resistance to gastrointestinal nematodes. Veterinary Parasitology, v. 98, n. 1-3, p. 51-64, 2001. http://dx.doi.org/10.1016/S0304-4017(01)00423-X

GORDON, H. M.; WHITLOCK, H. V. A new technique for counting nematode eggs in sheep faeces. Journal of Council for Scientific Industrial Research, v. 12, n. 1, p. 50-52, 1939.

GUIMARÃES, M. P. et al. Intensidade parasitária por nematódeos no tubo digestivo de bezerros em diferentes faixas etárias. Arquivos da Escola de Veterinária da Universidade Federal de Minas Gerais, v. 27, n. 1, p. 67-72, 1975.

KEITH, R. K. The differentiation on the infective larvae of some common nematode parasites of catlle. Australian Journal of Zoology, v. 1, n. 2, p. 223-235, 1953. http://dx.doi.org/10.1071/ZO9530223

LIMA, W. S. Seasonal infection pattern of gastrointestinal nematodes of beef cattle in Minas Gerais State -Brazil. Veterinary Parasitology, 
v. 74, n. 2-4, p. 203-214, 1998. http://dx.doi.org/10.1016/S03044017(97)00164-7

MOLENTO, M. B. Resistência de helmintos em ovinos e caprinos. Revista Brasileira de Parasitologia Veterinária, v. 13, p. 82-87, 2004. Suplemento 1.

ROBERTS, F. H. S.; O'SULLIVAN, P. J. Methods for egg counts and larval cultures for strongyles infecting the gastro-intestinal tract of cattle. Australian Journal of Agricultural Research, v. 1, n. 1, p. 99-102, 1950. http://dx.doi.org/10.1071/AR9500099

ROBERTS; F. H. S.; O'SULLIVAN, P. J.; RIEK, R. F. The significance of faecal egg counts in the diagnosis of parasitic gastro-enteritis of cattle. Australian Veterinary Journal, v. 27, n. 1, p. 16-18, 1951. PMid:14800846. http://dx.doi.org/10.1111/j.1751-0813.1951. tb00024.x
SOUTEllo, R. G. V.; SENO, M. C. Z.; AMARANTE, A. F. T. Anthelmintic resistance in cattle nematodes in northwestern São Paulo State, Brazil. Veterinary Parasitology, v. 148, n. 3-4, p. 360-364, 2007. PMid:17656022. http://dx.doi.org/10.1016/j.vetpar.2007.06.023

SOUZA, A. P. et al. Resistência de helmintos gastrintestinais de bovinos a anti-helmínticos no Planalto Catarinense. Ciência Rural, v. 38, n. 5, p. 1363-1367, 2008. http://dx.doi.org/10.1590/S010384782008000500026

VERCRUYSSE, J.; DORNY, P. Integrated control of nematode infections in cattle: A reality? A need? A future? International Journal for Parasitology, v. 29, n. 1, p. 165-175, 1999. http://dx.doi.org/10.1016/ S0020-7519(98)00192-1

YAMAGUTI, S. Systema helminthum: The nematodes of vertebrates. New York: Interscience Publisher Inc., 1961. v. 3, 679 p. 